PontIFícIA UNIVERSIDADE CATÓLICA dO RIO DE JANEIRO

\title{
Atributos dos Artistas Gospel que Influenciam Clientes na Decisão de Compra
}

Allan Cesar

Trabalho de Conclusão de Curso

Centro de CIÊnCIAS SOCIAIS - CCS

DepartamEnTo de AdMINISTRAÇÃo

Graduação em Administração de Empresas 
Allan Cesar

\section{Atributos dos Artistas Gospel que Influenciam Clientes na Decisão de Compra}

Trabalho de Conclusão de Curso

Trabalho de Conclusão de Curso, apresentado ao programa de graduação em Administração da PUC-Rio como requisito parcial para a obtenção do título de graduação em Administração.

Orientador: Daniel Kamlot

Rio de Janeiro, dezembro de 2016. 
"Porque Dele, por Ele e para Ele, são todas as coisas; glória, pois, a Ele eternamente. Amém."

(Romanos 11: 36) 


\section{Agradecimentos}

Em primeiro lugar, agradeço a Deus por ter me ajudado em todos os momentos que pareciam impossíveis de serem superados durante essa minha caminhada, e por ter me dado saúde para enfrentá-los e vencê-los.

Agradeço a toda minha família pela força, amor e incentivo que prestaram durante minha jornada na faculdade. Em especial, meus pais, Milton e Noemia e meus irmãos, Cristiano e Viviane, que sem eles não conseguiria chegar até aqui.

Aos meus amigos, que puderam me ajudar nos momentos complicados e por passarem em todas as etapas dessa longa jornada juntos comigo. Em especial, meus amigos Fabiana, Geovane, Raffaella, Tayná e Thalissa que viveram intensamente esses anos com muito companheirismo.

Ao meu orientador, Daniel Kamlot, que foi fundamental para a conclusão desse trabalho. Um grande prazer e honra ter sido orientado por ele. Aprendi muito.

$E$, por fim, a todos os professores que exerceram brilhantemente seus papéis e que, sem dúvidas, foram pessoas que influenciaram minha vida durante esse tempo na PUC-Rio. Sem eles, certamente, não viveria isso. 


\section{Resumo}

CESAR, Allan.; KAMLOT, Daniel. Atributos dos artistas gospel que influenciam os clientes na decisão de compra. Rio de Janeiro, 2016. p. 39 Trabalho de Conclusão de Curso - Departamento de Administração. Pontifícia Universidade Católica do Rio de Janeiro.

O mercado de música gospel vem crescendo muito no Brasil, atingindo inúmeros adeptos ao seu estilo musical. Um grande fator desse crescimento é o grande número de artistas que estão envolvidos nesse meio, atingindo estilos diversos, desde o pop-rock ao axé gospel.

Com isso, o consumidor de música gospel possui diversas opções para comprar os produtos de quem mais admira. Contudo, espera-se que o mesmo avalie os atributos de cada artista conforme seus ideais e crenças. Para tanto, este estudo verificou o comportamento consumidor de música gospel quanto aos seus hábitos de compra, suas motivações e atitudes, além de identificar nesse mercado, que é pouco explorado, suas principais características.

Palavras- chave

Mercado de música gospel, Comportamento do Consumidor, Atributos dos Artistas Gospel, Motivação, Atitude, Hábitos de Compra. 


\section{Abstract}

CESAR, Allan.; KAMLOT, Daniel. Attributes of gospel artists that influence customers in the buying decision. Rio de Janeiro, 2016. p. 39 Final Course Work - Administration Departament. Pontifícia Universidade Católica do Rio de Janeiro.

The gospel music industry has been growing significantly in Brazil, attracting numerous followers of its music style. A major factor for such rapid growth is the great number of artists who are involved in this particular market exploring the most diverse genres, ranging from pop-rock to axé music.

Thus, the gospel music fan benefits from several options of product of whomever he/she admires the most. However, it is expected that every consumer evaluates carefully the attributes of each artist according to their personal ideals and beliefs. Therefore, this study analyzed the consumer behavior in the gospel industry in regard to their buying habits, motivations, and attitudes, besides identifying the main features of this music genre, which is still little explored.

\section{Key-words}

Gospel Music Market, Consumer Behavior, Attributes of Gospel Artists, Motivation, Attitude, Purchase habits. 


\section{Sumário}

1 O tema e o problema de estudo 1

1.1. Introdução ao tema e ao problema do estudo 1

1.2. Objetivo final do estudo 2

1.3. Objetivos intermediários do estudo 2

1.4. Delimitação do estudo 2

1.5. Justificativa e relevância do estudo 3

2 Revisão de literatura $\quad 4$

2.1. O mercado de música gospel no Brasil 4

2.1.1. Características da música gospel 4

2.1.2. Diversidade dos cantores gospel no Brasil 5

2.1.3. Características do consumidor de música gospel 6

2.2. O processo de decisão de compra: modelo de cinco estágios 7

$\begin{array}{ll}\text { 2.2.1. Reconhecimento do problema } & 7\end{array}$

2.2.2. Busca de informações 8

2.2.3. Avaliação de alternativas 9

2.2.4. Decisão de compra 9

2.2.5. Comportamento pós-compra 10

2.3. Motivação 11

2.3.1. Teoria da hierarquia das necessidades 11

$\begin{array}{lr}\text { 2.4. Atitude } & 12\end{array}$

3 Métodos e procedimentos de coleta e de análise de dados do estudo 14

3.1. Etapas de coleta de dados 14

3.2. Fontes de informação selecionadas para coleta de dados no estudo14

3.3. Procedimentos e instrumentos de coleta de dados utilizados no estudo

3.4. Formas de tratamento e análise dos dados coletados para o estudo 17

3.5. Limitações do método 
4 Apresentação e análise dos resultados $\quad 18$

4.1. Música gospel 18

4.1.1. Descobrimento da música gospel e aceitação de outros estilos $\begin{array}{ll}\text { musicais } & 18\end{array}$

4.1.2. Características e temas das músicas gospel 20

4.1.3. Estilos mais aceitos $\quad 21$

4.1.4. Estilos alternativos na igreja 22

4.2. Cantores mais ouvidos 23

4.3. Formas de consumo $\quad 24$

4.4. Características e motivações para o consumo 25

4.5. Meios de pesquisa e avaliação $\quad 27$

4.6. Fatores que adiam a compra 28

4.7. Pós-compra do consumidor 30

4.8. Atitudes relacionadas à compra 31

5 Conclusões e recomendações para novos estudos 33

5.1. Sugestões e recomendações para novos estudos 34

6 Referências Bibliográficas $\quad 35$

Anexo A: Roteiro com os consumidores 38

Anexo B: Critérios de Renda - Modelo IBGE 39

\section{Lista de figuras}

Figura 1: Pirâmide de Maslow 
Lista de Quadros

Quadro 1: Entrevistados.................................................................. 15

Quadro 2: Atividades nas igrejas que frequentam .................................... 16 


\section{0 tema e o problema de estudo}

Este capítulo volta-se à apresentação do tema que se pretende desenvolver e do problema de estudo. Assim, apresenta-se o problema que suscitou a proposta de investigação e respectivos objetivos de pesquisa. $\mathrm{Na}$ sequência, são indicadas as suposições e as hipóteses do estudo, sua relevância, justificativa, bem como a delimitação e foco do mesmo.

\subsection{Introdução ao tema e ao problema do estudo}

Nos últimos anos, o mercado de música gospel tem conquistado espaço e se consolidado no gosto do público brasileiro (MARTINS, 2014). O setor de música gospel mantém crescimento de cerca de $15 \%$ ao ano e possui um faturamento anual de 1,5 bilhões e já está entre os 20 estilos mais vendidos no Brasil atualmente, ultrapassando muitos artistas da Música Popular Brasileira (ALVES, 2015). Landmann e Strutz (2012) acrescentam que o mercado de música gospel vem agradando todos os tipos de públicos e com isso atinge novos fãs e vendas bem lucrativas.

Um dos principais fatores para o crescimento do mercado é uma vasta variedade de artistas gospel que se encontram nesse meio, o que permite ao consumidor uma maior abrangência no momento da escolha dos discos. Além disso, novas gerações surgem para renovar o setor, como por exemplo, Eli Soares, Bruna Karla, Thalles Roberto, Arianne, Mariana Valadão, setor esse antes dominado por nomes famosos como, Cassiane, Aline Barros, Fernanda Brum, Kleber Lucas e Oficina G3 (ALVES, 2015).

Atualmente é cada vez mais natural que as gravadoras abram espaço para o mercado de música gospel, afinal, $30 \%$ dos brasileiros são evangélicos e potenciais consumidores. Há uma perspectiva de daqui a 15 anos serem metade do Brasil (CARVALHO, 2014).

Desde 2010, grandes gravadoras, como por exemplo a Sony Music, Som Livre e Universal Music despertaram o interesse no mercado de música gospel e passaram a competir com as principais gravadoras exclusivas desse tipo de mercado, como por exemplo a MK Music, Gospel Records e Line Records 
(LEVINO, 2011). Landmann e Strutz (2012) afirmam que as gravadoras tratam esse mercado como especial e diferenciado, o que motiva a criação de um segmento voltado para esse público.

Com a grande variedade de artistas no mercado de música e perspectivas de crescimento desse mercado, surgiu então o problema central do estudo, que se expressa pelo seguinte questionamento: Quais os atributos dos artistas gospel que influenciam os consumidores nas decisões de compra de produtos do mercado de música gospel?

\subsection{Objetivo final do estudo}

O presente estudo tem como objetivo final identificar quais os principais atributos dos artistas gospel que influenciam os consumidores nos momentos de decisão de compra de produtos ligados à música gospel.

\subsection{Objetivos intermediários do estudo}

Com a finalidade de atingir o objetivo final do estudo, pretende-se:

- Analisar o mercado de música gospel e suas características;

- Identificar os hábitos dos consumidores de música gospel durante processo de decisão de compra;

- Identificar as motivações e atitudes do consumidor de música gospel relacionados ao comportamento da compra dos produtos ligados a esse mercado.

\subsection{Delimitação do estudo}

O presente estudo terá como foco apenas os consumidores de música gospel que habitam no Rio de Janeiro e será realizado no ano de 2016. Pretende-se buscar consumidores com idade mínima de 18 anos de ambos os sexos. Além disso, a pesquisa não focará em apenas cantores, mas, também em bandas.

Não se pretende com este estudo propor soluções ou alternativas para que as empresas que trabalham nesse tipo de mercado possam atrair ou fidelizar clientes, mas identificar os atributos dos artistas gospel que sejam mais valorizadas pelo consumidor. 


\subsection{Justificativa e relevância do estudo}

Este estudo torna-se relevante para empresas que trabalham no mercado de música gospel, pois será possível compreender o que os consumidores julgam mais importantes de um artista para decidirem comprar os seus produtos, possibilitando assim promover ou adaptar ações de comunicação com a finalidade de atingir ou aproximar mais o seu público-alvo.

Além disso, pode-se considerar que este estudo contribua com os dados aqui presentes para outras pesquisas acadêmicas que estejam focadas nesse assunto, haja vista que existem poucos trabalhos que abordem sobre 0 comportamento de compra, as motivações e atitudes dos consumidores de música gospel. 


\section{Revisão de literatura}

Neste capítulo são apresentados e discutidos aspectos conceituais e estudos relacionados ao tema e estudo em investigação e que servirão de base para a análise realizada.

\subsection{0 mercado de música gospel no Brasil}

A música gospel progrediu bastante no Brasil, passando a fazer parte da maioria das igrejas evangélicas do Brasil. Atualmente, elas passaram a ter estruturas muito bem equipadas para que nelas fossem feitos cultos e shows, além de realizar outros tipos de eventos (CALDAS, 2008).

Landmann e Strutz (2012) citam que, atualmente, as igrejas promovem shows dos mais simples até os mais apoteóticos, atraindo inúmeras pessoas por todo o país. Para isso, os músicos passaram a não serem somente cantores de música gospel, mas a serem considerados artistas, com pagamento de cachês e outros benefícios.

Entretanto, Paula (2012) afirma que o mercado de música gospel está ampliando cada vez mais suas fronteiras para fora dos circuitos de distribuição das instituições evangélicas e das empresas como gravadoras, rádios, pontos de vendas e igrejas. Caldas (2008) afirma que a distribuição e comercialização dos produtos evangélicos estão além dos limites das lojas especializadas em artigos gospel, passando a estar na seção de prateleiras de supermercados e lojas de varejo em geral. Segundo Paula (2012), essa expansão tem beneficiado a divulgação do repertório musical desse mercado e atingido potenciais clientes que não frequentavam pontos de vendas especializados.

\subsubsection{Características da música gospel}

A música gospel tem características diferentes em comparação a outros estilos musicais. Nesse gênero, que é bastante amplo, podem-se esperar inúmeras tendências musicais que passam a fazer parte da vida dos consumidores do meio evangélico. A característica fundamental da música gospel é a busca em adorar a Deus (SANTOS, 2013). Landmann e Strutz (2012) 
afirmam que a música gospel se adapta com qualquer estilo, entretanto, suas letras precisam falar de Deus, textos bíblicos ou ter palavras de fé, tornando-se então, totalmente tendenciosa para que o consumidor possa ter uma vida mais regrada pela doutrina cristã. Visão semelhante tem Cunha (2007) que acrescenta que as letras das músicas gospel precisam chamar à conversão e ao apego de Jesus Cristo, além de exaltar o nome de Deus. Além disso, a música gospel tem por característica a não utilização de palavrões.

Os temas das músicas gospel variaram durante o tempo, afinal, atualmente, há letras com a temática romântica. Este tipo de tema tem sido mais abordado ultimamente por artistas como Fernanda Brum, Aline Barros, Cassiane e Jairinho, entre outros, e bandas como Novo Som. Existem, também, outros artistas que compõem canções mais reflexivas, como Sérgio Lopes e o Grupo Logos, por exemplo, pois suas composições fazem com que o consumidor pense sobre algum assunto ou comportamento na igreja (SANTOS, 2013).

Historicamente, os ritmos que são os mais tradicionais no meio gospel são o pop, o rock e o sertanejo (CUNHA, 2007). Entretanto, segundo Santos (2013), pode-se notar uma grande diversidade no mercado gospel que vem crescendo desde a década de 80 , com a vinda de novos ideais e estilos, além de novos pensamentos que vieram à tona na sociedade. Cunha (2007) afirma que o mercado gospel cedeu espaço para outros ritmos musicais como, rap, funk, forró, hip-hop, reggae, samba, pagode e axé. Santos (2013) acrescenta que diferentes mudanças aconteceram ou estão acontecendo a respeito de vários assuntos, usos e costumes, comportamentos etc., entretanto, vale ressaltar que algumas igrejas ainda tentam permanecer fiéis aos modelos nos quais as mesmas foram fundadas.

Isto se reflete muito no estilo musical que é tocado nesses templos. Por exemplo, em determinadas igrejas não se pode ou podia tocar guitarra ou bateria, pois pensam ou pensavam ter ligação com a obscuridade, entretanto, em outras é permitido tocar esses instrumentos e quaisquer ritmos sem maiores perturbações (SANTOS, 2013).

\subsubsection{Diversidade dos cantores gospel no Brasil}

Atualmente, o meio gospel possui uma grande variedade de artistas, de diferentes gêneros, que cada vez mais estão se qualificando musicalmente e se profissionalizando (CALDAS, 2008). Santos (2013) também afirma que é comum ver que os músicos evangélicos estejam cada vez mais se aprimorando 
tecnicamente, seja para o mercado ou apenas para tocar nas igrejas. Cunha (2007) cita que, vindos das igrejas ou do mercado secular, a quantidade de artistas gospel permanece crescendo.

Segundo Caldas (2008), com essa grande diversidade de estilos musicais no meio evangélico, muitos artistas, de modo geral, estão adotando estilos que não eram considerados apropriados para o ambiente religioso, como o funk, forró ou música eletrônica. Porém, apesar de apresentar toda essa diversidade e suas respectivas performances, o ambiente religioso possui ideologias e práticas peculiares que se aplicam na utilização da música dentro do seu contexto; por exemplo, não é permitido, o uso de maconha em shows de reggae.

Atualmente, encontram-se diversos artistas com características físicas diversas como cabelos longos, pintados ou com cortes trançados, tatuados, com brincos, sem camisa, utilizando piercings. Além disso, a forma de cantar, tocar e dançar se aproxima de forma bem semelhante dos shows que acontecem fora do ambiente gospel (CALDAS, 2008). Cunha (2007) afirma que, mesmo com grande diversidade, os artistas gospel preferem serem chamados de "adoradores" ao invés de "artistas".

\subsubsection{Características do consumidor de música gospel}

Segundo Macedo (2006), o consumidor de música gospel considera a música uma forma de comunicação e influenciadora sobre a vida das pessoas. Além disso, são consumidores eventuais de CDs e não usufruem de CDs piratas. Entretanto, quando gostam de um artista, tornam-se e permanecem fiéis a ele, pois acreditam que são "abençoados" ao comprarem seus produtos (CUNHA, 2007).

O consumidor de música gospel, quando compra um CD de algum artista desse mercado, em geral preza pela qualidade das letras, pela concordância entre o discurso das letras e a prática de vida e afinidade com o ritmo. Além disso, são flexíveis para ouvir músicas que não sejam do meio gospel (MACEDO, 2006). Landmann e Strutz (2012) também corroboram que as letras e o ritmo são os atributos mais cativantes na escolha de um artista gospel, pois são características influenciadoras pela mensagem que passam. Cunha (2007) afirma que ao comprar um $\mathrm{CD}$, o consumidor de música gospel se utiliza muito da emoção, pois acredita que os artistas são "instrumentos de Deus" para adorar a Deus e guerrear contra o mal. 
Segundo Macedo (2006), o consumidor de música gospel também demonstra uma visão crítica quanto ao mercado gospel. Ele considera que alguns artistas assumem papéis que não representam os verdadeiros ideais cristãos, mas que desejam apenas o sucesso financeiro. É comum que os clientes deixem de comprar CDs e outros materiais, caso o perfil do artista não se enquadre com os ideais cristãos. Para esse consumidor, os artistas gospel precisam ir além das qualidades técnicas, caso contrário, tendem a ser estigmatizados mesmo sendo bons artistas.

\subsection{O processo de decisão de compra: modelo de cinco estágios}

Segundo Kotler e Keller (2012), o processo de decisão de compra é fundamental para entender as decisões tomadas pelos consumidores. Esse processo começa antes da compra final e pode ter consequências duradouras. Sobral e Peci (2008) afirmam que a decisão de compra é um processo e não é um simples momento, e que suas consequências geram impactos além da compra.

Os cinco estágios para a decisão de compra caracterizam-se por: reconhecimento do problema, busca de informações, avaliação de alternativas, decisão de compra e comportamento pós-compra (LAMB, JUNIOR e MCDANIEL, 2004).

Porém, nem sempre os consumidores se utilizam desses cinco estágios para adquirir um produto. Eles podem pular ou inverter alguma delas (KOTLER e KELLER, 2012).

\subsubsection{Reconhecimento do problema}

É o primeiro momento do processo de decisão de compra do consumidor (SOBRAL e PECI, 2008). Lamb, Junior e McDaniel (2004) afirmam que esse estágio começa quando a condição real e a desejada do consumidor estão em desequilíbrio. Kotler e Keller (2012) acrescentam que esse estágio começa quando há necessidades ou problemas que são reconhecidos pelos consumidores.

Esse reconhecimento pode ser incentivado quando o consumidor for exposto a estímulos internos ou externos (LAMB, JUNIOR e MCDANIEL, 2004). No caso de estímulos internos, as necessidades normais dos consumidores sobem para um nível de consciência e tornam-se um impulso. Já no caso de 
estímulos externos, as necessidades são provocadas por propagandas ou por admiração do produto de um amigo, por exemplo (KOTLER e KELLER, 2012).

\subsubsection{Busca de informações}

Segundo Lamb, Junior e McDaniel (2004), este estágio ocorre quando o consumidor, que já está interessado em adquirir determinada mercadoria, busca mais informações para satisfazer a sua necessidade. Solomon (2011) também menciona que esse é o processo pelo qual o cliente irá procurar informações adequadas às suas necessidades para embasar sua decisão. Sobral e Peci (2008) afirmam que esse estágio depende da complexidade da compra. À medida que o produto for mais complexo, ou seja, quanto mais caro ou importante o produto for para o consumidor, mais informações serão necessárias.

Para tal, as principais fontes de informação que o consumidor utiliza são: fontes pessoais, caracterizadas pela família e amigos dos consumidores; fontes comerciais, que são as propagandas, vendedores e embalagens; fontes públicas, que se caracterizam pelos meios de comunicação de massa; e as fontes experimentais, que são os manuseios de produtos por meio de amostra (KOTLER e KELLER, 2012). Durante a busca de informações, o consumidor pode usufruir de mais de uma fonte a fim de que possa ter a maior satisfação possível (SOBRAL e PECI, 2008).

Segundo Kotler e Keller (2012), o consumidor recebe a maior quantidade de informações através das fontes comerciais, entretanto, as informações mais efetivas são das fontes pessoais e públicas. Vale ressaltar que a Internet ganhou um papel muito importante nas buscas de informações, pois tem crescido a utilização desse meio para consultar sobre algum produto.

Lamb, Junior e McDaniel (2004) afirmam que por meio da busca de informações, o cliente escolherá inúmeras marcas que julga serem as suas preferidas. Kotler e Keller (2012) mencionam que através da obtenção das informações sobre os produtos, o consumidor conhece as marcas concorrentes e seus atributos, e, portanto, quanto maior a quantidade de informações obtidas, o consumidor escolherá as melhores alternativas para compra do produto. 


\subsubsection{Avaliação de alternativas}

Este estágio começa depois de ter aglomerado todas as informações que garantam um nível de segurança satisfatória e, a partir dessas, o consumidor começará a avaliar todas as alternativas e possibilidades satisfatórias e insatisfatórias para compra (SOBRAL e PECl, 2008). Entretanto, essa não é uma etapa tão fácil de realizar, pois, nesse instante, o consumidor se coloca diante das diversas opções que a sociedade de consumo oferece (SOLOMON, 2011).

Segundo Kotler e Keller (2012), no momento de avaliar as alternativas possíveis para a escolha de determinado produto, os consumidores buscam os benefícios que o mesmo pode oferecer para a satisfação de suas necessidades. Engel, Blackwell e Miniard (2000) acrescentam que esse é o momento do cliente buscar os resultados desejados visando aos atributos que julga serem os preferidos. Nesse instante, o consumidor institui suas prioridades entre as marcas com a finalidade de comprar as que foram as favoritas (KOTLER e KELLER, 2012).

Lamb, Junior e MCDaniel (2004) afirmam que o consumidor irá, nesse momento, utilizar as informações coletadas para desenvolver critérios para comparar e avaliar as alternativas. Cada critério utilizado para avaliar todas as alternativas necessárias é escolhido para alcançar os objetivos de compra desejados (SOBRAL e PECI, 2008).

A partir disso, os clientes prestarão mais atenção aos atributos de cada produto a fim de oferecerem os benefícios esperados (KOTLER e KELLER, 2012). Vale ressaltar que um cliente, em sua escolha de alternativas, pode avaliar cuidadosamente múltiplas marcas, enquanto outro cliente, em uma solução mais rotineira, pode não considerar outra alternativa à sua marca de sempre (SOLOMON, 2011).

\subsubsection{Decisão de compra}

Este estágio caracteriza-se pelo momento em que o cliente decide comprar determinado produto, considerando seus atributos, de suas marcas preferidas (KOTLER e KELLER, 2012).

Segundo Engel, Blackwell e Miniard (2000), neste estágio, nem sempre as intenções de compra do consumidor são efetuadas, porque o cliente pode encontrar algum fator que o faça desistir do processo. Segundo Kotler e Keller 
(2012), a decisão de um cliente em modificar ou adiar uma compra é influenciada pelos riscos percebidos, que são definidos assim:

- Risco funcional: ocorre quando o produto não corresponde às expectativas.

- Risco físico: ocorre quando o produto ameaça o bem-estar ou a saúde do cliente.

- Risco financeiro: ocorre quando o produto não vale o preço.

- Risco social: ocorre quando o produto causa um constrangimento.

- Risco psicológico: ocorre quando o produto afeta o bem-estar mental do consumidor.

- Risco de tempo: ocorre quando a ineficiência de um produto gera um custo de oportunidade para encontrar um substituto satisfatório.

O risco percebido pode estar presente caso o produto seja caro ou complexo e o consumidor tenha dificuldade de entender (SOLOMON, 2011). Kotler e Keller (2012) também afirmam que o grau de risco percebido se modifica de acordo com a quantidade de dinheiro envolvido, mas acrescentam que o nível de incerteza referente aos atributos e o nível de autoconfiança do cliente também contribuem para tal acontecimento.

A não ser que haja algum imprevisto, a compra é efetivada após todas as análises realizadas (SOBRAL e PECI, 2008).

\subsubsection{Comportamento pós-compra}

Após a compra, o consumidor aguardará por alguns resultados. À medida que as expectativas sejam atendidas, resultará se o cliente ficará satisfeito ou insatisfeito com a realização da compra (LAMB, JUNIOR e MCDANIEL, 2004). Sobral e Peci (2008) acrescentam que esse último estágio fornecerá mais informações sobre o consumidor referentes a novas compras futuras (SOBRAL e PECI, 2008).

Segundo Kotler e Keller (2012), a satisfação do cliente resulta da comparação entre suas expectativas e a performance percebida do produto. À medida que a performance do produto não atinge as expectativas, o consumidor fica insatisfeito, podendo abandonar ou devolver o produto, reclamar com a empresa, e, consequentemente desistir de uma nova possibilidade de compra do produto. Sobral e Peci (2008) dizem que, em casos de insatisfação com o produto, o cliente pode obter algum tipo de compensação e, posteriormente, 
fazer mais uma vez todos os estágios de compra para corrigir os erros que houve durante o processo. Caso o produto alcance as expectativas, o cliente fica satisfeito, gerando a possibilidade de fidelização (ENGEL BLACKWELL e MINIARD, 2000). Sobral e Peci (2008) afirmam que o consumidor tenderá a comprar novamente o mesmo produto da mesma marca, a fim de evitar novos riscos relacionados a uma nova marca.

\subsection{Motivação}

Schiffman e Kanuk (2000) descrevem motivação como uma força motriz que age internamente nos indivíduos e que os dirigem à ação. De acordo com Kotler e Keller (2012), a motivação é um impulso que o consumidor tem para que o mesmo possa agir, a fim de suprir uma necessidade fisiológica ou psicológica. Visão semelhante têm Sobral e Peci (2008), que afirmam que a motivação do indivíduo é uma predisposição para exercer algum esforço para satisfazer alguma necessidade.

Segundo Schiffman e Kanuk (2000), os consumidores irão se esforçar para satisfazerem suas necessidades. Porém, o modo como essa necessidade é atendida vai depender da história do indivíduo, de suas experiências de aprendizagem e do seu ambiente cultural (SOLOMON, 2011).

\subsubsection{Teoria da hierarquia das necessidades}

A teoria de motivação foi criada por Abraham Maslow e explica a razão pela qual os clientes são motivados por necessidades particulares em alguns momentos da vida (KOTLER e KELLER, 2012). Sobral e Peci (2008) complementam dizendo que o comportamento do consumidor para comprar determinado produto é impulsionado por estímulos internos de cada consumidor, que são estados de carência ou privação. O motivo para que isso aconteça é que as necessidades humanas dos clientes são colocadas em uma hierarquia numa escala das necessidades mais urgentes para as menos urgentes. Elas se caracterizam por necessidades fisiológicas, necessidades de segurança, necessidades sociais, necessidades de estima e necessidades de autorealização (LAMB, JUNIOR e MCDANIEL, 2004).

Segundo Schiffman e Kanuk (2000), à medida que o consumidor satisfaz uma necessidade menor, ele tenta suprir a próxima mais importante. Sobral e Peci (2008) corroboram afirmando que somente quando uma necessidade 
inferior é satisfeita, o consumidor se sente estimulado para satisfazer outra necessidade superior. Essa teoria é útil para compreender as motivações do cliente de como determinados produtos satisfazem cada nível de suas necessidades (SCHIFFMAN e KANUK, 2000).

Figura 1: Pirâmide de Maslow

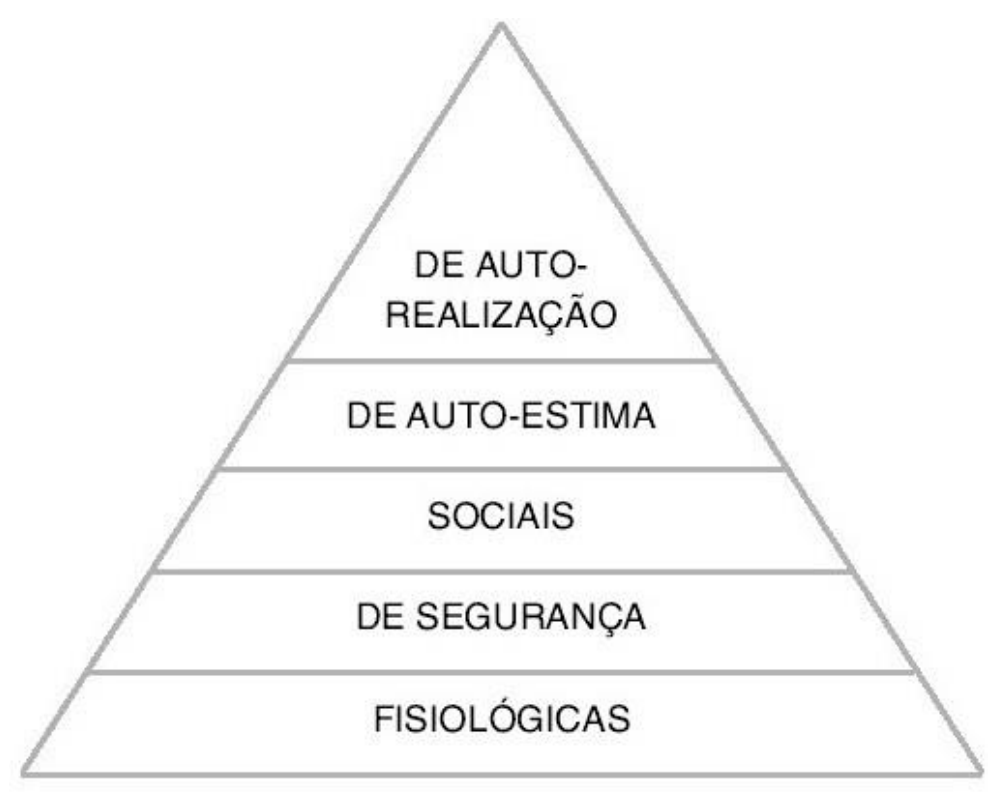

Fonte: Ebah (2013)

\subsection{Atitude}

Segundo Sobral e Peci (2008), a atitude representa as predisposições do consumidor para agir sobre a compra de determinado produto. Schiffman e Kanuk (2000 p.167) definem atitude como: "expressão dos sentimentos mais íntimos que refletem se uma pessoa está favorável ou desfavoravelmente inclinada para algum objeto".

Schiffman e Kanuk (2000) afirmam que as atitudes são aprendidas através da experiência direta com determinado produto, da propaganda ou de outras formas de marketing direto. Além disso, podem gerar o comportamento de compra, embora o consumidor possa não exercê-lo obrigatoriamente. Já Gade (1980) afirma que as atitudes são formadas pela influência da família, já que é o primeiro momento do indivíduo interagindo socialmente, ou de um grupo relevante do qual a pessoa faz parte, isto é, algum grupo de amigos ou colegas de trabalho. 
As atitudes dificilmente mudam e levam o cliente a se comportar de forma coerente frente a objetos semelhantes (KOTLER e KELLER, 2012).

As atitudes possuem três componentes básicos que se relacionam para uma decisão de compra: o cognitivo, o afetivo e o comportamental (GADE, 1980).

Gade (1980) define o componente cognitivo como as crenças, ou seja, todas as informações e experiências passadas que o indivíduo viveu e que formaram seu corpo de crenças e que geralmente são percebidos como boas ou ruins, e, a partir disso, o indivíduo poderá agir pela compra de um produto ou não.

O componente afetivo é definido por Schiffman e Kanuk (2000) como as emoções e os sentimentos que o indivíduo possui sobre um produto. Gade (1980) complementa afirmando que esses sentimentos ou emoções podem ser ligados a favor ou contra um produto.

Já o componente comportamental refere-se à relação com a probabilidade ou tendência de que o indivíduo irá ou não ter a intenção de compra sobre determinado produto (SCHIFFMAN e KANUK, 2000). Gade (1980) também cita que caso o indivíduo tenha uma atitude favorável sobre determinado produto, ele terá uma tendência de agir de maneira também favorável. Caso contrário, o consumidor tenderá a agir de maneira desfavorável sobre o produto.

Engel, Blackwell e Miniard (2000) afirmam que determinado produto, para alguns indivíduos, pode ser baseado principalmente nas crenças, visando apenas aos benefícios funcionais de um produto, por exemplo. Já para outro produto, as atitudes podem ser baseadas principalmente pelas emoções, visando obter as experiências que o produto pode proporcionar. Solomon (2011) complementa dizendo que tanto as emoções quanto as crenças podem predominar em cada indivíduo durante o processo de compra de algum produto. 


\section{Métodos e procedimentos de coleta e de análise de dados do estudo}

Este capítulo pretende informar sobre as diversas decisões sobre a forma como este estudo foi realizado.

\subsection{Etapas de coleta de dados}

Com o objetivo de entender sobre a opinião e o comportamento do consumidor de música gospel suas atitudes e motivações, esta etapa de coleta de dados caracterizou-se por um estudo exploratório, que segundo Samara e Barros (2002) tem por características principais ser informal, flexível e criativo onde se deseja conseguir um contato inicial com o problema a ser pesquisado ou um melhor conhecimento do objeto estudado. Podem ser realizados a partir de dados secundários ou conversas informais com as pessoas. A principal vantagem desse tipo de estudo é o alcance de informações com um custo baixo, entretanto, sua desvantagem é a eventual obsolescência dessas informações por falta de atualização.

Foi realizada uma pesquisa de campo qualitativa para coletar os dados da pesquisa junto aos consumidores de música gospel com entrevistas em profundidade.

\subsection{Fontes de informação selecionadas para coleta de dados no estudo}

Foi realizada uma coleta de dados primários durante os meses de outubro e novembro de 2016 junto aos consumidores de música gospel. A maneira de selecionar as pessoas componentes da amostra foi por conveniência, que é a que possui menos rigor para a escolha dos entrevistados, pois o entrevistador seleciona aqueles que possuem maior facilidade de acesso (GIL, 2007).

Foram realizadas treze entrevistas (Quadro 1) no Rio de Janeiro para realizar uma análise dos resultados obtidos. Elas foram realizadas 
pessoalmente, não havendo a necessidade de utilizar contatos virtuais ou telefônicos.

\section{Quadro 1: Entrevistados}

\begin{tabular}{|c|c|c|c|c|c|}
\hline № & Sexo & $\begin{array}{l}\text { Faixa de Renda } \\
\text { Familiar }\end{array}$ & Idade & Escolaridade & Igreja \\
\hline E1 & $\mathrm{F}$ & 2 a 4 SM & 34 & $\begin{array}{l}\text { Superior } \\
\text { Completo }\end{array}$ & Advec Penha \\
\hline E2 & M & 10 a 20 SM & 36 & $\begin{array}{c}\text { Superior } \\
\text { Incompleto }\end{array}$ & Advec Vila da Penha \\
\hline E3 & M & 10 a 20 SM & 20 & $\begin{array}{c}\text { Superior } \\
\text { Incompleto }\end{array}$ & Advec Vila da Penha \\
\hline E4 & $M$ & 4 a $10 S M$ & 25 & $\begin{array}{l}\text { Superior } \\
\text { Completo }\end{array}$ & Igreja Ceifa \\
\hline E5 & $\mathrm{F}$ & 4 a 10 SM & 23 & $\begin{array}{l}\text { Superior } \\
\text { Completo }\end{array}$ & Igreja Ceifa \\
\hline E6 & M & 4 a 10 SM & 28 & $\begin{array}{l}\text { Superior } \\
\text { Completo }\end{array}$ & Igreja Ceifa \\
\hline E7 & $F$ & 4 a 10 SM & 23 & $\begin{array}{c}\text { Superior } \\
\text { Incompleto }\end{array}$ & Igreja Ceifa \\
\hline E8 & $\mathrm{F}$ & 4 a 10 SM & 22 & $\begin{array}{c}\text { Superior } \\
\text { Incompleto }\end{array}$ & Advec Penha \\
\hline E9 & $M$ & 4 a 10 SM & 29 & Pós-graduação & Advec Penha \\
\hline E10 & $\mathrm{M}$ & 2 a 4 SM & 27 & $\begin{array}{c}\text { Ensino Médio } \\
\text { Completo }\end{array}$ & Vida Plena \\
\hline E11 & $\mathrm{F}$ & 4 a 10 SM & 29 & Pós-graduação & Advec Penha \\
\hline E12 & $M$ & 4 a $10 S M$ & 30 & $\begin{array}{c}\text { Superior } \\
\text { Incompleto }\end{array}$ & Advec Penha \\
\hline E13 & M & 10 a 20 SM & 35 & $\begin{array}{l}\text { Superior } \\
\text { Incompleto }\end{array}$ & $\begin{array}{c}\text { Assembleia de Deus } \\
\text { da Vila da Penha }\end{array}$ \\
\hline
\end{tabular}

Fonte: O próprio autor (2016)

\subsection{Procedimentos e instrumentos de coleta de dados utilizados no estudo}

Foram coletadas as respostas através de entrevistas em profundidade. Gil (2007) define entrevista como uma técnica de que o entrevistador se utiliza para formular perguntas aos seus entrevistados a fim de conseguir as informações pertinentes à sua investigação. Já que o estudo tem por objetivo entender o comportamento do consumidor de música gospel, suas motivações e atitudes frente a esse tipo de mercado, a entrevista tem como vantagem a possibilidade de ser mais flexível, tendo em vista que o entrevistador pode explicar o significado das perguntas e se adaptar às pessoas. Por fim, a entrevista permite 
captar a expressão corporal do entrevistado, seu tom de voz e ênfase nas perguntas (GIL, 2007).

O roteiro da entrevista foi elaborado tendo em vista o conceito de entrevista focalizada, que segundo Gil (2007), tem um foco em um tema específico, cujo entrevistador permite ao entrevistado falar abertamente sobre o assunto, entretanto, caso o entrevistado se desvie do tema proposto, o entrevistador precisa se esforçar para que possa retornar ao mesmo.

Para entender mais sobre o perfil do entrevistado, foram realizadas perguntas referentes aos seus dados pessoais e suas atividades nas igrejas em que frequentam (Quadro 2). Quanto à renda dos entrevistados, foi utilizado o critério do Instituto Brasileiro de Geografia e Estatística (IBGE). O roteiro das entrevistas encontra-se no anexo $A$ e as faixas de renda familiar encontram-se no anexo $B$.

\section{Quadro 2: Atividades nas igrejas que frequentam}

\begin{tabular}{|c|c|}
\hline No & \\
\hline E1 & $\begin{array}{l}\text { De duas a três vezes na semana vai a igreja. Dá o dízimo e oferta. Recepcion } \\
\text { os convidados na igreja e acompanha os novos convertidos. }\end{array}$ \\
\hline E2 & $\begin{array}{c}\text { Cantor e líder de louvor da igreja. Vai a igreja, pelo menos, duas vezes na } \\
\text { semana. Dizimista e ofertante. }\end{array}$ \\
\hline E3 & $\begin{array}{c}\text { Vice-líder e líder do louvor dos adolescentes e dá aula na Escola Dominical. } \\
\text { Dizimista e ofertante. Vai à igreja duas vezes na semana. }\end{array}$ \\
\hline E4 & $\begin{array}{l}\text { Líder de jovens e guitarrista no louvor da igreja. Dizimista e ofertante. Pelo } \\
\text { menos duas vezes na semana está na igreja. }\end{array}$ \\
\hline E5 & $\begin{array}{l}\text { Líder de jovens e canta no louvor da igreja. Dizimista e ofertante. Frequenta a } \\
\text { igreja, pelo menos, duas vezes na semana. }\end{array}$ \\
\hline E6 & $\begin{array}{l}\text { Pastor da igreja e líder de louvor. Tem uma banda que atua no mercado. } \\
\text { Frequenta a igreja entre duas e três vezes na semana. Dizimista e ofertante }\end{array}$ \\
\hline E7 & $\begin{array}{c}\text { Auxilia o trabalho do pastor da igreja e canta no louvor. Frequenta a igreja } \\
\text { entre duas e três vezes na semana. Dá o dízimo e ofertas. }\end{array}$ \\
\hline E8 & $\begin{array}{l}\text { Líder da dança dos adolescentes. Só não está } 100 \% \text { na igreja por causa dos } \\
\text { estudos. Frenquenta três vezes na semana a igreja. Dizimista e ofertante. }\end{array}$ \\
\hline E9 & $\begin{array}{l}\text { Líder da produção dos adolescentes. Dizimista e ofertante. Está na igreja duas } \\
\text { vezes na semana. }\end{array}$ \\
\hline E10 & $\begin{array}{l}\text { Não exerce nenhuma atividade, mas gosta de fazer trabalhos braçais na igreja, } \\
\text { como produção. Dizimista e ofertante. Geralmente, vai à igreja aos domingos. }\end{array}$ \\
\hline E11 & $\begin{array}{l}\text { Atualmente só assiste ao culto. Oferta na igreja, mas direciona o dízimo pra } \\
\text { alguma causa social. Está na igreja uma vez na semana. }\end{array}$ \\
\hline E12 & $\begin{array}{l}\text { Foi líder de adolescentes. Hoje não exerce nenhuma atividade na igreja. } \\
\text { Oferta na igreja e dá o dízimo para causas sociais. Frequenta só aos domingos. }\end{array}$ \\
\hline E13 & $\begin{array}{l}\text { Novo na igreja onde frequenta. Recentemente começou a cantar na igreja. } \\
\text { Dizimista e ofertante. Por causa do trabalho, está na igreja uma ou duas vezes }\end{array}$ \\
\hline
\end{tabular}




\subsection{Formas de tratamento e análise dos dados coletados para o estudo}

Foi utilizada a análise do discurso como forma de tratamento das informações obtidas através de entrevistas.

Vergara (2012) define análise do discurso como uma técnica para fins exploratórios que visa entender e descobrir o sentido de uma mensagem transmitida, quer esteja explícito ou não. A subjetividade do pesquisador é um meio utilizado nas interpretações de cada discurso.

À medida que as entrevistas foram realizadas, as mesmas foram transcritas para auxiliar a análise. Em seguida, o discurso de cada entrevistado foi relacionado com os dos demais indivíduos e com o referencial teórico que deu o suporte para a investigação a fim de identificar padrões e verificar possíveis similaridades e inconsistências entre os discursos.

Por fim, após a análise do discurso, foram resgatados os objetivos do presente trabalho a fim de concluir, com as informações levantadas, as devidas interpretações e conclusões.

\subsection{Limitações do método}

Algumas limitações que podem ocorrer quando se avalia a entrevista, mesmo sendo considerada um bom método para pesquisa, é quanto à falta de motivação do entrevistado nos momentos das respostas durante o andamento das entrevistas e o possível fornecimento de respostas que não representem a verdadeira opinião, quer seja por razões conscientes ou inconscientes (GIL, 2007).

Há também um fator importante na pesquisa qualitativa. McDaniel e Gates (2003) afirmam que os estudos qualitativos não representam a população como um todo, mas a representatividade só é constatada junto a uma pesquisa quantitativa. Entretanto, para uma pesquisa acadêmica como esta, o método escolhido parece ser adequado.

Por ser um método que conta com a subjetividade do entrevistador para analisar o que foi dito, uma limitação da análise do discurso é a interpretação equivocada daquilo que de fato o entrevistado queria dizer, quer seja por falta de sensibilidade do entrevistador ou por informações imprecisas ou insuficientes do entrevistado (GIL, 2007). 


\section{Apresentação e análise dos resultados}

Este capítulo, organizado em oito seções, apresenta e discute os principais resultados alcançados durante as entrevistas realizadas.

\subsection{Música gospel}

Esta seção tem como objetivo entender os gostos, influências e opiniões de cada entrevistado a respeito do mercado de música gospel e sobre outros estilos que estão além do gospel. Para tanto, esta seção foi dividida em quatro: descobrimento da música gospel e aceitação de outros estilos musicais; características e temas da música gospel; estilos mais aceitos e estilos alternativos na igreja.

\subsubsection{Descobrimento da música gospel e aceitação de outros estilos musicais}

Os entrevistados mostraram grande influência dos pais ao descobrirem a música gospel em suas vidas.

Descobri a música gospel através de meus pais. Na verdade, através de minha mãe. Eu escuto desde criança. - E1

Comecei a ouvir a música gospel com 12 anos, porque foi quando o meu pai se converteu. Então foi ele que me apresentou. Num primeiro momento eu comecei a ouvir a música gospel na rádio mesmo. - E9

Pode-se perceber que a música gospel tem grande representatividade na vida de seus consumidores. Para eles, a música os completa, edifica e inspira. Esse fato corrobora Macedo (2006), que afirma que a música gospel é influenciadora sobre a vida das pessoas.

Cara, ela me completa. Com uma variedade de músicas hoje, você tem uma série de artistas que conseguem suprir qualquer situação da sua vida. - E9 A música gospel pra mim, me edifica e me inspira. - E10 
Contudo, quando perguntados se ouvem outros estilos musicais além do meio gospel, as repostas foram bem variadas.

Alguns entrevistados responderam que ouvem e que não têm problema algum em ouvir outros estilos além do gospel. Colaborando com o que Macedo (2006) afirma, isto é, que os consumidores de música gospel são flexíveis em ouvir outros estilos musicais.

...Sem ser o gospel eu ouço Sandy. Geralmente é o que eu ouço. Porque eu sou apaixonada por ela. Meu sonho é ir num show dela. Gosto do estilo musical e das letras dela. Tudo o que ela escreve eu me identifico. - E8

...Eu sou muito eclético e, às vezes, eu quero alguma coisa na música que no gospel não tem. Aí eu escuto MPB, Jazz, Blues, Samba e isso não é voltado para o gospel. - E3

Houve também respondentes que ouvem não apenas por gostarem de outros estilos, mas por uma questão de trabalho.

...Com certeza (ouve outros estilos). Hoje o meu trabalho não me permite ouvir as músicas gospel. Então coloco uma música tranquila na rádio do carro. Às vezes tem muita música americana que não entendo a letra, mas acho o ritmo dela bacana. - E12 - Motorista de Uber.

...Ouço (outros estilos musicais). Ouço música internacional para trabalho e pra lazer. Eu sou professora de inglês. - E11

Entretanto, houve alguns respondentes que já ouviram ou não ouvem outros estilos musicais além do gospel por não causarem nenhuma "edificação" em suas vidas e pelo gospel suprir as necessidades de ritmos parecidos com os outros estilos. Este fato corrobora Caldas (2008), que afirma que a música gospel se aproxima de forma semelhante aos shows que acontecem fora do ambiente gospel, na forma de cantar e tocar.

...Cara, já ouvi mais (outros estilos musicais), hoje não ouço não. Ouvia muito o rock americano, mas isso quando eu tinha uns 15, 16 anos. Mas agora, 99\% é gospel e $1 \%$ é o que toca no vizinho. - E4

...Não ouço (outros estilos musicais). Assim, ouço nas festas de alguém ou do vizinho. Mas eu colocar na minha casa, não. Lá eu coloco mesmo uma música gospel. Não 
ouço mais música que não seja gospel porque não me edifica muito. Eu acho que a música gospel me edifica como pessoa e como serva de Deus. Então eu evito de ouvir esse tipo de música (que não seja gospel). - E7 ... Não ouço (outro estilo musical). Eu não tenho interesse porque o meio gospel abrange todos os ritmos. Então eu não tenho necessidade escutar algo fora do gospel. - E9

\subsubsection{Características e temas das músicas gospel}

Notou-se que as características principais das músicas gospel são a adoração a Deus e a propagação da palavra (bíblia). Isso confirma o que é exposto por Santos (2013), que afirma que a característica fundamental da música gospel é a busca da adoração a Deus.

Pra mim, adorar a Deus é o principal. Me faz chegar mais próximo de Deus, me faz ter mais tranquilidade. - E12

A característica principal é propagar a palavra de Deus... Porque aquelas pessoas que não leem a bíblia, através de uma música elas podem conhecer o que a bíblia diz. Ela precisa falar sobre a Bíblia. - E5

Quanto aos temas, verificou-se grande diversidade. Contudo, eles precisam estar baseados na bíblia e falar de Deus, mesmo que implicitamente. Outros temas citados que a música precisa falar foram o amor, a fé, compaixão, salvação e assuntos que te façam refletir.

Primeiro precisa falar de Deus, de alguma forma, senão não é. Claro que dentro de uma poesia você consegue trazer a divindade dentro da canção sem necessariamente falar a palavra "Deus" ou "Jesus". Tem que ter base na bíblia... Por exemplo, existem músicas proféticas, que te levam a um nível mais profundo na fé. Tem músicas de guerra, que te preparam quando você sai de um local (Igreja) renovado, com força. Existem canções que te façam refletir e existe a adoração mesmo. Aquela que só exalta e louva sem pedir nada ou fazer referência a qualquer tipo de tema. - E2

Ela tem que falar sobre Deus. Tem que falar sobre Deus e sobre aquilo que ele é, de fato. - E6 
Cara, de tema, tem que falar o básico. Salvação, libertação. Tem que confrontar. A maioria nos leva a adoração. É o principal propósito. Pra mim, adoração é o principal, mas precisa falar de salvação, libertação e cura. $-E 10$

Hoje em dia o gospel abriu muito. Hoje tem músicas gospel que falam de amor, de família. Tem até aquele CD "Amo você" do volume 1 até... Eu perdi as contas. Ali você encontra não só temas de Deus, mas alguns mais voltados para o lado de família, relacionamento, comunhão entre o homem e uma mulher. E ela precisa ter letra e, principalmente, precisa ter adoração. Ela precisa falar sobre isso porque ela é voltada totalmente pra Deus. - E13

Esses relatos contribuem para o que Landmann e Strutz (2012) afirmam, que a música gospel precisa falar de Deus, textos bíblicos ou ter palavras de fé, e, com o que Santos (2013) também cita que atualmente as músicas possuem temas mais românticos ou reflexivos.

\subsubsection{Estilos mais aceitos}

Quanto aos estilos que são os mais ouvidos ou comprados pelos consumidores, destacaram-se os mais tradicionais como o pop, pop-rock e o rock britânico, ratificando o que Cunha (2007) declara: que esses são os ritmos mais tradicionais no meio gospel. Contudo, notou-se também influências dos estilos afro-americanos como o black, o soul e o jazz, por serem estilos mais apreciados na parte instrumental.

Eu gosto do pop, pop-rock e um rock britânico. - E8

Pop-rock é legal. Agora estou ouvindo bastante jazz. - E4

Hoje eu gosto de pop, pop-rock. Mas gosto muito de ouvir o blues, o jazz, por uma questão instrumental mesmo. Eu aprecio essa parte instrumental. - E5

Dentro do gospel hoje, eu curto ouvir muita coisa, porque acho que enriquece a gente. Desde o axé, reggae, rockpop. Mas, estilos que eu interpretaria estaria mais voltado para adoração. Uma coisa bem mais lenta, voz e violão. 


$$
\begin{aligned}
& \text { E, o rock-pop ou o rock britânico que é o que está } \\
& \text { "bombando" hoje. - E2 }
\end{aligned}
$$

Pode-se perceber também uma peculiaridade presente durante as entrevistas. Alguns entrevistados afirmaram que o estilo que preferiam era o de adoração. Contudo, a adoração não é um considerado um estilo musical, porém um tema. Quando perguntados o que significava o "estilo adoração" notou-se que eram músicas mais lentas, frequentemente usadas com voz e violão ou o pop-rock.

Agora, se for falar em relação à igreja, eu acho que o estilo tem que ser de adoração, um estilo mais lento, que te leva mais à reflexão. - E1

Cara, o que eu mais me identifico é a adoração. Porque é o que faz me aproximar mais de Deus. A adoração é um estilo que me atrai mais pra Deus. - E10

Eu gosto de adoração. Eu ouço de tudo, mas esse é o meu preferido. Adoração é uma música mais lenta. - E11

\subsubsection{Estilos alternativos na igreja}

Referente aos estilos alternativos nas igrejas, as opiniões foram bastante diversas.

De acordo com alguns entrevistados, pode-se observar certa resistência dos estilos alternativos durante o andamento do culto, pois os mesmos não são próprios para esse tipo de momento, contudo é válido em outras ocasiões, como festas ou cultos com públicos específicos. Fato que confirma com Caldas (2008), que afirma que o ambiente religioso possui certas práticas e ideologias peculiares que se aplicam apenas em seu contexto, fazendo com que algumas igrejas permaneçam em seus estilos tradicionais.

Eu gosto disso. Eu acho que o forró, funk, axé é bom pra um momento de festa, mas no culto não tem um sentido. Eu não percebo um sentido. Fica fora do contexto. Você vai pra um culto de celebração e lá vai tocar músicas agitadas, mas não um forró. Numa festa gospel sim! - E1 Eu acho legal esses estilos alternativos dentro da igreja. Depende mesmo do público. Por exemplo, se a gente tocasse um funk gospel num culto só de mulheres, 
senhoras, isso não iria edificá-las. Mas se fosse vários jovens que acabaram de "aceitar Jesus", seria legal. - E7

Dentro da igreja talvez não goste muito. Mas acho que numa festa cabe. - E11

Entretanto, houve entrevistados que não enxergavam nenhum problema em ter estilos como funk, forró ou rap dentro da igreja, afinal a letra é mais importante que o estilo.

Então eu não vejo problema nenhum. Pelo contrário, eu acho muito bom que tenha os diversos estilos porque não é o estilo que vai dizer se é gospel ou se é pecado. $O$ estilo é simplesmente a levada da música. A diversidade é muito válida. Pra mim, dentro da igreja, não tem problema nenhum. - E6

Quanto aos estilos alternativos, eu acho uma boa... não vejo problema de tocar um pagode ou funk dentro da igreja. - E3

\subsection{Cantores mais ouvidos}

Caldas (2008) afirma que há uma grande diversidade de artistas gospel atuando nesse mercado. Para tanto, verificou-se entre os entrevistados nomes bem variados que atuam em gêneros diferentes. Contudo, os artistas do poprock se destacaram mais, entre eles Fernandinho, Davi Sacer, Leonardo Gonçalves, André Valadão, Nívea Soares e as bandas Livres para Adorar, cujo líder é o cantor Juliano Son e Diante do Trono, cuja líder é a cantora Ana Paula Valadão. As justificativas para a escolha desses artistas foram a presença do estilo com que mais se identificam, a forma como elas passam as canções e a qualidade das letras que são compostas.

Eu gosto da Nívea Soares, porque eu gosto das ministrações e da forma que ela canta. Eu consigo me identificar com ela. Diante do trono, por conta das letras. Eu acho incríveis as letras deles. - E8 Gosto muito do Fernandinho, Davi Sacer, Leonardo Gonçalves. Gosto muito do André Valadão. As letras desses caras são maravilhosas. - E13

Eu gosto muito do Fernandinho, Diante do Trono, Nívea Soares... Eu me identifico com o tipo de música e louvor 
deles. O estilo musical deles é parecido com o meu. Gosto do Juliano Son também, ouço muito. - E7

Notou-se ainda o gosto e a admiração de alguns entrevistados por cantores e bandas internacionais, também pelo fato de se identificarem com os ritmos e as letras das músicas. Destacam-se os grupos norte-americanos Bethel Music, Jesus Culture e o grupo australiano Hillsong e o cantor americano Israel Houghton.

Mas eu escuto muita música americana também, como Bethel, que escuto muito. Eu escuto muito porque é o meu estilo. Eu consigo me identificar. - E3

No meio internacional eu ouço muito Israel Houghton, Jesus Culture e ouvia bastante Hillsong, mas eles deram uma diminuída. O estilo me chama mais atenção, o jeito que eles levam a música e a letra também. - E4

\subsection{Formas de consumo}

Macedo (2006), em seus estudos, afirmou que os consumidores de música gospel são eventuais compradores de CDs, contudo, notou-se dentre os entrevistados o pouco hábito de comprar CDs atualmente. A forma mais utilizada pelos entrevistados para comprar CDs é quando o próprio artista vai até a igreja e lá vende seus produtos.

Eu já comprei, mas não sou de ficar comprando sempre. Às vezes o cantor vai fazer sua adoração lá no culto e ele leva CDs para vender. - E1

Cara, eu compro CD pra ajudar, mas não ouço o CD não. Às vezes vem um cantor na igreja e você gosta muito, aí eu compro, mas não ouço. - E3

Eu não vou até a loja comprar. Geralmente é quando é exposto na minha igreja ou em algum lugar que eu vou ouvir eles cantarem. - E8

Faz tempo que não compro $C D$. - E11

Pode-se notar que os entrevistados tem um hábito maior de comprar DVDs pelo fato de conseguirem ter o show por inteiro visto em suas casas. Além disso, são consumidores que possuem o hábito de comprar no momento do lançamento do produto. 
Hoje eu compro mais DVD. Por exemplo, no lançamento do DVD da Nívea Soares eu comprei. Fernandinho e Preto no Branco também. - E4

$C D$ é muito mais raro. Eu prefiro comprar DVD porque eu assisto. Geralmente eu compro DVD quando tem um lançamento legal. - E6

Outro hábito constante identificado foi que quase a totalidade dos entrevistados se utilizam de downloads para escutar alguma música ou o $C D$ completo dos artistas. Esse é o principal motivo identificado pelo desinteresse da compra pelos CDs físicos. Esse público não tem o costume de pagar pelos downloads.

Prefiro ter a música em formato mp3 que eu posso ouvir no meu celular. Questões tecnológicas mesmo. Faço downloads, mas não pago por eles. A maioria é free. - E5 Eu faço downloads também. Pelo 4shared. Mas não pago. $-E 6$

\subsection{Características e motivações para o consumo}

Foi possível identificar que as motivações de consumo para a compra do CD ou de quaisquer produtos dos artistas estão diretamente ligadas aos atributos que os mesmos possuem.

Notou-se que, quando compram algum produto do artista de que gostam, os entrevistados são motivados de acordo com o que Macedo (2006) afirma. Os consumidores de música gospel são motivados pela qualidade da letra do cantor, pela concordância entre o discurso das letras e a prática de vida e por afinidade com o ritmo.

Primeiro ele tem que passar sinceridade e verdade ao cantar para que eu possa ver se o que ele canta, ele vive. Segundo é o ritmo, porque eu reparo a "pegada" e todo lance mais técnico. E, o cara precisa ter letra. Se não tiver letra fica ruim. - E3

Acho que o músico, de tudo que ele canta, ele tem que viver aquilo. Ele tem que ter em mente de que ele precisa edificar as pessoas com aquilo que ele vive. Se ele fala que Deus é fiel, ele precisa viver e crer na fidelidade de 
Deus. Não pode faltar na vida diária uma entrega a Deus.

Não pode faltar isso. Cantando e vivendo aquilo - E7

Também foi observado que os artistas gospel precisam ter uma vida que represente os ideais cristãos, isto é, ser cristão, viver uma vida com Deus e viver segundo a bíblia.

Primeiramente ele precisa ter uma história com Deus. É inevitável. - E13

Tem que ser uma pessoa de Deus. Que seja comprometida com o reino e não só pensa em dinheiro. E11

É viver de acordo com o que está na palavra de Deus, embora isso possa parecer um pouco difícil ou um pouco complicado. A base de todo cristão deveria ser a bíblia sagrada. $-E 1$

Schiffman e Kanuk (2000), ao explicarem a teoria da hierarquia das necessidades de Maslow, afirmam que uma necessidade maior só pode ser suprida à medida que uma necessidade mais urgente e menor tenho já sido suprida. Lamb, Junior e McDaniel (2004) classificam essas necessidades, em uma ordem de mais importante para menos importantes, como fisiológicas, de segurança, sociais, de estima e de auto-realização.

Percebeu-se então que, mesmo com todas as características que motivam os entrevistados para a compra, ter o CD de um artista gospel não é uma necessidade urgente ou essencial, mas é comparado a uma necessidade de auto-estima ou auto-realização, segundo a pirâmide de Maslow.

Se eu tiver um conta pra pagar e tiver que comprar um $C D$, claro que eu vou preferir a conta pra pagar porque $o$ $C D$ é uma coisa supérflua pra mim. Eu não preciso do $C D$ pra sobreviver. - E1

Eu me sinto feliz. É como se fosse uma conquista, uma realização. - E1, quando perguntada sobre o sentimento de ter o CD de um artista que gosta.

Às vezes você tem o dinheiro pra comprar, mas tem a faculdade, o trabalho, seu pai precisa de alguma coisa, seu filho está chorando... - E13

É um sentimento de alegria em saber que aquilo que está sendo cantado faz parte da minha vida. É um sentimento único porque em qualquer momento eu posso colocar pra 
ouvir no meu quarto ou no meu carro. É uma realização mesmo. - E13, quando perguntado sobre o sentimento de ter o CD de um artista que gosta.

\subsection{Meios de pesquisa e avaliação}

No momento de buscar informações para comprar o CD de um artista gospel, Kotler e Keller (2012) definem as principais fontes como comerciais, pessoais, públicas e experimentais. Portanto, notou-se nas entrevistas que a fonte mais utilizada pelos consumidores de música gospel é a pessoal, ou seja, o entrevistado se utiliza dos amigos para buscar informações sobre algum produto de um artista.

Os amigos, pra ver o que eles indicam ou falam a respeito de um artista. - E1

Além da internet, só os amigos. Às vezes a gente conversa e as pessoas indicam e aí eu procuro saber. E8

A gente também procura através de colegas $e$ conhecidos. - E13

Contudo, Sobral e Peci (2008) afirmam que o consumidor pode usufruir de mais de uma fonte de informação e Kotler e Keller (2012) citam a Internet com uma grande importância como meio de pesquisa e busca de informações.

Para tanto, os entrevistados, em sua totalidade, afirmaram que se utilizam da internet para buscar informações sobre os artistas e os seus produtos. Destacam-se as redes sociais, como o Facebook e o Instagram, e o site de vídeos YouTube como principais meios de pesquisas. Alguns sites especializados no universo gospel também foram citados, como o Verdade Gospel, Super Gospel e Gospel Prime.

Internet passa tudo pra gente. História, dia em que nasceu, enfim, tudo do cara. - E12

Gosto de pesquisar em sites. Tem o Verdade Gospel, o Super Gospel, o Gospel Prime que são sites que falam sobre os cantores, os lançamentos, as novidades. Então é basicamente a internet. - E9

Assim, como eu gosto de alguns, eu sigo alguns deles no Instagram e alguns no Facebook. As redes sociais. Só. E7 
$\mathrm{Na}$ avaliação de algum artista antes da compra de um produto, os entrevistados gastam tempos variados. As respostas variaram entre horas ou meses.

$$
\begin{aligned}
& \text { Na verdade, pelo fato de eu não ter um preferido, a gente } \\
& \text { demora muito. Além do fato também de ter tantos } \\
& \text { cantores gospel. Então acaba demorando sim. Pode } \\
& \text { durar dias ou até meses pode acontecer. - E1 } \\
& \text { Eu tenho que ouvir umas cinco músicas, pelo menos. Eu } \\
& \text { não gosto de julgar o cara na primeira música. Porque tu } \\
& \text { pode ouvir a música ruim do cara, entendeu? Aí eu } \\
& \text { determino se compro ou não. Isso demora horas ou } \\
& \text { minutos, talvez. - E3 }
\end{aligned}
$$

No entanto, quando decidem comprar após a avalição, os entrevistados tendem a, numa próxima compra, tomar uma decisão mais rotineira sem precisar considerar outras alternativas ou fazer novas avaliações. Colaborando com o que Solomon (2011) afirma que numa solução mais rotineira, o consumidor pode não considerar outras alternativas à sua marca de sempre.

Por exemplo, eu aprendi a gostar da Eyshila (cantora gospel). Eu não gostava dela. Mas, eu fui vendo que ela vivia o que cantava e, pela sinceridade que ela passa, eu compro o CD dela. Qualquer CD que ela gravar e lançar, eu vou comprar. - E3

O (DVD) da Nívea já está no DVD. Nem tirei. Aí eu invisto de novo. Próximo lançamento a gente já compra sem ver. $-E 4$

\subsection{Fatores que adiam a compra}

Notou-se durante as entrevistas que o principal fator que pode adiar a compra de algum produto de um artista gospel é o financeiro, o que contribui para o que Kotler e Keller (2012) afirmam, que o risco financeiro é um fator que pode fazer com que a compra não seja efetuada.

Finanças (pode adiar uma compra). Por exemplo, o DVD hoje custa de 30 a 40 reais. Então você tem que pesar. Se eu conhecer o cara e for legal isso coopera pra compra. - E4 
A única coisa que pode me fazer adiar mesmo é a falta de grana. É a única. - E10

Contudo, com bastante frequência, outro fator que pode fazer com que a compra não seja efetuada é quanto a algum escândalo em que o artista possa se envolver que não esteja de acordo com os ideais cristãos.

Um desvio de conduta. Às vezes você está louco pra comprar e o cara faz uma coisa que te decepciona como pessoa. Aí a música dele fica em vão pra você. Esse cara não merece o meu centavo. - E6

Acontece também de alguns se envolverem em alguns escândalos e, dependendo do que aconteceu, algo que envergonhou o evangelho, você começa meio que duvidar e aí isso pode adiar também. - E7

Eu já deixei de comprar um produto de um determinado cantor que estourou muito rápido e com uma personalidade musical muito nova e isso era muito incomum no nosso costume de tipo de música. Mas ele teve certos comportamentos que mostraram que ele não é um cara cristão ou um cara dentro daquilo que eu acredito que um cantor cristão tem que ser, e aí eu desisti de comprar o produto dele, mesmo gostando do trabalho que ele havia feito. Então eu não compro porque não acho que acrescenta mais. - E5

Alguns entrevistados também afirmaram que um outro fator que pode causar o adiamento da compra é o fato de não acompanhar mais o artista por ele ter sumido da mídia.

Cara, tem o David Quinlan (de quem deixou de comprar os produtos), mas porque ele deu uma sumida. Se ele tivesse na mesma pegada de sempre eu estaria comprando. - E4

David Quinlan sempre gostei, mas está um pouco sumido da mídia e não tenho buscado muito. - E5 


\subsection{Pós-compra do consumidor}

Durante as entrevistas, à medida que um produto satisfaz cada entrevistado, as ações mais comuns depois da compra é o fato de continuar ouvindo a música por diversas vezes e indicar para seus amigos.

Quando me satisfaz, eu escuto muito ele e divulgo bastante. Sugiro ele pra algumas pessoas. Eu falo: "Cara, compra esse aqui porque eu garanto." - E6

Quando me satisfaz, eu ouço várias vezes. Inclusive tenho vários $C D$ s que eu acho que os meus vizinhos não aguentam mais ouvir. Porque eu não paro de ouvir. $O C D$ ou o DVD pode ser de 2008, mas se eu gostei, eu ouço ele até 2016. - E8

Quando me satisfaz, eu ouço muito e falo demais para as pessoas. Eu presenteei um amigo meu com o DVD do Davi Sacer. Dei o meu pra ele e comprei um outro pra mim. $-E 12$

Quando me satisfaz, eu ouço toda hora. Até por osmose. $-E 13$

Quando me satisfaz, eu ouço praticamente todo o dia. Para onde eu vou, eu vou ouvindo a música até enjoar dela. - E2

Em alguns casos os entrevistados se tornaram fiéis ao artista, concordando com o que Engel, Blackwell e Miniard (2000) afirmaram, que quando um produto satisfaz ao consumidor, há a possibilidade de fidelização.

Quando me satisfaz, eu ouço sempre. O da Nívea já está no DVD. Nem tirei. Aí eu invisto de novo. Próximo lançamento a gente já compra sem ver. - E4

Quando me satisfaz, com certeza eu indico e se eu tiver condições, eu compro uns dois ou três. - E10

Caso o produto não satisfaça, os entrevistados afirmaram que não fazem nada, apenas deixam de usufruir do produto, concordando com Kotler e Keller (2012), que afirmam que, quando as expectativas não são atingidas, o consumidor tende a abandonar esse item.

Aí eu parto pra outra. Quando um CD não me satisfaz eu mando para escanteio. Só pego se precisar. - E2 
Quando não gosto eu deixo de lado. Totalmente esquecido. - E5

Quando não me satisfaz eu deixo guardado. - E11

\subsection{Atitudes relacionadas à compra}

Durante a realização das entrevistas, verificou-se que os entrevistados possuem uma atitude desfavorável referente aos artistas que não representam os ideais e que continuam na música gospel apenas para ganhar dinheiro. Esse tipo de comportamento faz com que o consumidor não compre mais os produtos desse artista, fato que reafirma o que Gade (1980) expõe, isto é, caso o indivíduo tenha uma atitude que não seja favorável sobre um produto ou uma situação, o consumidor tenderá a agir de maneira desfavorável.

Infelizmente, eu ainda acredito que sim (que existam artistas que não representam os ideais cristãos, mas estão no meio gospel), que seja uma realidade. Eu acho que ele está por causa de dinheiro. Infelizmente, eu falo triste isso porque não deveria ser esse o caso. Acho que alguns perderam a essência da adoração, o servir e focaram na essência do ganhar. Alguns perderam esse foco. $-E 7$

Sim (existem artistas que não representam os ideais cristãos, mas estão no meio gospel). Porque atrai demais. É muito atrativo o mercado gospel. Ele cresceu muito. Financeiramente falando, é bem vantajoso. Tem muitos que, infelizmente, fazem isso. Por marketing ou por ter retorno imediato. Esse tipo de coisa a gente vê por aí. - E13

Contudo, quando os entrevistados compram um CD de um artista que representa os ideais cristãos que eles acreditam, a atitude é bem favorável.

É um sentimento de satisfação e de alegria. Porque é um momento esperado. A gente fica naquela expectativa ouvindo os teasers e quando sai, você se sente realizado ouvindo aquele $C D$. - E9

Cara, eu fiquei muito feliz. Por exemplo, o DVD do Leonardo Gonçalves, eu consegui pegar um autógrafo 


$$
\begin{aligned}
& \text { dele. É um sentimento de felicidade. Eu fico } \\
& \text { entusiasmado. }-E 10
\end{aligned}
$$

Notou-se também, no momento das escolhas dos produtos para exercer a compra, decisões que envolvem de forma predominante a emoção pelo fato do produto Ihes fazer bem, o que corrobora com o que Cunha (2007) afirma - que o consumidor de música gospel se utiliza das emoções para comprar um CD - e também com o que Engel, Blackwell e Miniard (2000) afirmam - que para um produto cujas atitudes são baseadas em emoções, o indivíduo busca as experiências que o mesmo pode oferecer.

Me sinto edificada. Porque é algo que me ajuda muito, na minha vida. - E5

Se eu ouvir a música dele e conectou meu coração. Ualll. Isso aí já está valendo. É imediatamente. Se tocou no rádio e falou comigo, isso já basta. - E7

Mas, às vezes, tem um cara que não é muito bom, a voz dele também não é tão bonita ou tão doce, mas o cara é um adorador. O cara quando canta te faz sentir a presença de Deus. O cara é um levita mesmo. Ele tem algo a mais, além de só cantar. Este é o que mais me atrai. - E6

Outro fator importante é que foi percebido que há um sentimento positivo ao comprar um CD pelo fato de não só se sentir "edificado" e "abençoado" por ele, mas para também ajudar ao artista que vive da renda da venda dos CDs.

Eu me vejo valorizando o trabalho do cara. Porque hoje, com a internet, você tem acesso a qualquer música. É até mais rápido. Ao comprar o $C D$ de um cantor eu me vejo valorizando o trabalho dele. Dizendo que ele é bom, pra continuar com o trabalho. Me sinto muito bem e penso mais no outro do que em mim mesmo. - E3

Ah, cara. É de poder estar ajudando o mínimo o cantor. De certa forma eles (cantores) nos ajudam até mais do que nós a eles. As ministrações falam bem mais ao nosso coração do que a gente pode ajudar financeiramente. - E4

Sinto alegria. Porque você se sente como parte daquilo. Você se abençoa e abençoa o outro. - E11 


\section{Conclusões e recomendações para novos estudos}

O presente estudo teve como objetivo final identificar os atributos dos artistas gospel que mais influenciam os consumidores na decisão de compra. Para tanto, foi necessário entender as motivações e atitudes do consumidor referentes a esse mercado e seus hábitos durante o processo de decisão de compra de algum produto desse mercado.

Para atingir o objetivo final, realizou-se uma pesquisa com a visão de vários autores que puderam nortear o trabalho. Além disso, foram realizadas entrevistas com treze pessoas para entender sobre o comportamento desse consumidor específico.

Os resultados dessas entrevistadas permitiram a realização de análises para a conclusão, enfim, deste estudo.

Notou-se então que os atributos mais importantes dos artistas gospel e que influenciam aos consumidores de música gospel na decisão de compra são: as qualidades das letras escritas pelo cantor, a concordância entre o discurso das letras e a prática de vida e a afinidade com o ritmo do próprio consumidor. Portanto, pode-se notar que esses atributos são os principais fatores de motivação para os clientes comprarem seus produtos.

Contudo, mesmo com esses atributos, percebeu-se que a compra dos produtos não é uma necessidade essencial para os consumidores, mas detectou-se como uma necessidade de auto-estima e de realização. Portanto, caso tenham alguma necessidade de maior relevância em suas vidas, é possível que adiem a compra desse tipo de item.

Por fim, quanto às atitudes dos consumidores, percebeu-se grande aversão a artistas que só estão no mercado gospel por uma questão financeira e que não representam os ideais cristãos. Esse tipo de conduta leva o consumidor a deixar de comprar os produtos desse artista. Contudo, notou-se grande simpatia quanto a artistas que representam os ideais cristãos em que os consumidores acreditam. Há, nesse caso, a possibilidade de comprar seus produtos e permanecer fiéis a eles. Além disso, notou-se que as decisões são tomadas com base na emoção pelo fato dos produtos "edificarem" e "abençoarem" as suas vidas e pelo fato de serem agentes que também "abençoam" outros cantores. 


\subsection{Sugestões e recomendações para novos estudos}

Como recomendação para novos estudos, aconselha-se a expandir o presente estudo para além do Rio de Janeiro, atingindo outros estados do Brasil. Além disso, seria de grande valor a criação de uma pesquisa quantitativa a fim de atingir uma grande amostra da população para enriquecer as informações e conclusões realizadas no presente estudo, visto que este tem caráter exploratório.

Outra recomendação seria um aprofundamento quanto às atitudes desse público junto aos cantores gospel, tendo em vista que há um comportamento de não apenas ser "abençoado", mas de também ser um ajudador ao artista. Igualmente, é válido estudar até que ponto os consumidores adiam uma compra por causa de suas finanças se suas vidas são "edificadas" e "abençoadas" pelos cantores e suas composições. E também, verificar até que ponto a necessidade de comprar um produto do artista não é tão essencial, já que suas vidas são afetadas pela importância das canções do mesmo.

Também seria válido relacionar os hábitos do processo de compra do consumidor de música gospel, suas motivações e atitudes com os consumidores de outras religiões ou de adeptos de outros estilos musicais.

Por fim, o mercado e o consumidor de música gospel deveriam ser mais estudados no Brasil, tendo em vista que é um mercado em crescimento no atual cenário econômico do país e há numerosos consumidores adeptos desse tipo de mercado. 


\section{Referências Bibliográficas}

ALVES, Francisco Edson. Venda de CDs de cantores da música gospel supera ídolos da MPB. O Dia, Rio de Janeiro, 1 nov. 2015. Disponível em: http://odia.ig.com.br/noticia/rio-de-janeiro/2015-10-31/venda-de-cds-de-cantoresda-musica-gospel-supera-idolos-da-mpb.html. Acesso em: 22 abr. 2016.

CALDAS, Rebeca dos Santos. Indústria fonográfica gospel: a produção de música religiosa dentro das estratégias de mercado. Disponível em: http://www.cult.ufba.br/wordpress/24671.pdf. Acesso em: 02 ago. 2016.

CARVALHO, Pedro. O gospel é a próxima onda brasileira. UOL. Rio de Janeiro, 11 dez. 2014. Disponível em: http://musica.uol.com.br/noticias/redac ao/2014/02/11/o-gospel-e-a-proxima-onda-brasileira-diz-executivo-que-lancoumichel-telo.htm. Acesso em: 22 abr. 2016.

CUNHA, Magali do Nascimento. A explosão gospel: um olhar das ciências humanas sobre o cenário evangélico no Brasil. Rio de Janeiro: Mauad X: Instituto Mysterium, 2007.

ENGEL, James F.; BLACKWELL, Roger D.; MINIARD, Thomson. Comportamento do Consumidor. Tradução de Christina Ávila de Menezes. 9a ed. Rio de Janeiro: LTC, 2000.

GADE, Christiane. Psicologia do Consumidor. São Paulo: EPU, 1980.

GIL, Antonio Carlos. Métodos e Técnicas de Pesquisa Social. 5.ed. São Paulo: Atlas, 2007.

KOTLER, Philip.; KELLER, Kelvin Lane. Administração de Marketing. Tradução de Monica Rosenberg, Claudia Freire e Brasil Ramos Fernandes. 14a‥ed. São Paulo: Pearson Prentice Hall, 2012. 
LAMB, Charles W.; JUNIOR, Joseph F. Hair.; MCDANIEL, Carl. Princípios de Marketing. Tradução de Luciana Penteado Miquelino. $2^{\underline{a}}$ ed. São Paulo: Thomson, 2004.

LANDMANM, Maristela.; STRUTZ, Janete. Influência da música gospel na postura religiosa dos jovens enquanto prática discursiva. Revista Evento Pedagógicos. Disponível em: http://sinop.unemat.br/projetos/revista/index.php leventos/article/view/543. Acesso em: 02 set. 2016.

LAVILLE, Christian; DIONNE, Jean. A construção do saber: manual de metodologia da pesquisa em ciências humanas. Porto Alegre: Artes Médicas Sul; Belo Horizonte: EDUFMG, 1999.

LEVINO, Rodrigo. Música gospel: trinados, fé e dinheiro. Veja.com. Rio de Janeiro, 25 nov. 2011. Disponível em: http://veja.abril.com.br/noticia/entreteni mento/musica-gospel-trinados-fe-e-dinheiro. Acesso em: 22 abr. 2016.

MACEDO, Julio Cesar Silva. Comportamento de consumo dos jovens evangélicos no segmento da música: um estudo no interior do estado do Rio de Janeiro. Disponível em: livros01.livrosgratis.com.br/cp141275.pdf. Acesso em: 02 set. 2016.

MARTINS, Dan. Música gospel abraça diversos estilos e cria segmento de mercado atraente e lucrativo. Gospel Mais. Rio de Janeiro, 26 jul. 2014. Disponível em: http://noticias.gospe/mais.com.br/musica-gospel-segmentomercado-atraente-lucrativo-96768.html. Acesso em: 13 mai. 2016.

MCDANIEL, Carl D.; GATES, Roger. Pesquisa de marketing. Tradução: James F. Sunderland Cook. Revisão técnica: Tânia Maria Vidgal Limeira. São Paulo: Pioneira Thomson Learning, 2003.

PAULA, Robson Rodrigues de. O mercado da música gospel no Brasil: aspectos organizacionais e estruturais. Revista Uniabeu. Disponível em: http://www.uniabeu.edu.br/publica/index.php/RU/article/view/370/pdf_145.

Acesso em: 02 ago. 2016. 
SAMARA, Beatriz Santos.; BARROS, José Carlos de. Pesquisa de marketing: conceitos e metodologia. 3aㅗ ed. São Paulo: Prentice Hall, 2002.

SANTOS, Fábio Lopes dos. O Ensino e aprendizagem da música gospel: um olhar investigativo. Biblioteca Setorial da Escola de Música. Disponível em: https://monografias.ufrn.br/jspui/bitstream/123456789/1321/1/SANTOS,\%20F.\%2 OL.\%20dos_O\%20ensino\%20e\%20aprendizagem\%20da\%20m\%C3\%BAsica_20 13.pdf. Acesso em: 02 ago. 2016.

SCHIFFMAN, L. G.; KANUK, L. L. Comportamento do Consumidor. Tradução de Vicente Ambrósio. 6ª ed. Rio de Janeiro: LTC, 2000.

SOLOMON, Michael R. O Comportamento do Consumidor: Comprando, Possuindo e Sendo. Tradução de Luiz Claudio de Queiroz Faria. 9º ed. Porto Alegre, Editora Bookman, 2011.

SOBRAL, Filipe.; PECI, Alketa. Administração: teoria e prática no contexto

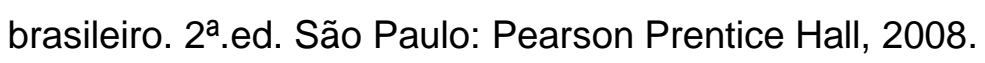

VERGARA, Sylvia Constant. Métodos de Pesquisa em Administração. 6.ed. São Paulo, Atlas, 2012. 


\section{Anexo A: Roteiro com os consumidores}

\section{Roteiro da entrevista}

\section{Introdução}

- Informar o entrevistado o conteúdo da entrevista e pedir autorização para gravar

\section{Música Gospel}

- Como você descobriu a música gospel? Desde quando ouve esse tipo de música? Você ouve outros estilos musicais?

- O que representa a música gospel para você?

- Para você, qual a característica principal da música gospel? O que ela precisa falar? Por quê?

- Quais estilos musicais dentro do gospel, você mais se identifica ou gosta? O que você acha dos estilos alternativos (funk, forró, axé) dentro das igrejas?

Cantores Gospel

- Quais cantores e bandas gospel que você mais gosta/ouve/compra? Por quê?

- Você compra CDs? Em quais ocasiões? Faz downloads? Paga por eles?

- Quais os atributos/características que você espera que um artista gospel tenha para você comprar o cd? Você já deixou de comprar algum produto de algum artista? Por quê?

- O que são os ideais cristãos para você?

- Você acredita que existem artistas gospel que não representam os ideais cristãos? Por que você acha que ele é um cantor gospel se ele não crê nos ideais cristãos?

\section{Decisão de Compra}

- Quais os meios que você utiliza para pesquisar sobre o artista e o produto?

- Você avalia um artista gospel novo antes de comprar os seus produtos? Quanto tempo, em média, você gasta com isso?

- Para você, o que pode adiar uma compra do produto do artista?

- O que você faz quando um CD não te satisfaz? E quando te satisfaz?

Motivação e Atitude

- Como você se sente ao comprar algum CD de um artista gospel de que você gosta?

Finalização

- Dados pessoais (ano de nascimento, escolaridade, gênero, idade e faixa de renda familiar) e agradecimento. 
Anexo B: Critérios de Renda - Modelo IBGE

\begin{tabular}{|c|c|c|}
\hline Classes & Salários Mínimos & Renda Familiar \\
\hline A & Acima de $20 \mathrm{SM}$ & $\mathrm{R} \$ 15.760,01$ ou mais \\
\hline B & 10 a 20 SM & De $R \$ 7.880,01$ a $R \$ 15.760,00$ \\
\hline C & 4 a 10 SM & De $R \$ 3.152,01$ a $R \$ 7.880,00$ \\
\hline D & 2 a 4 SM & De $R \$ 1.576,01$ a $R \$ 3.152,00$ \\
\hline $\mathrm{E}$ & Até $2 \mathrm{SM}$ & Até $\mathrm{R} \$ 1.576,00$ \\
\hline
\end{tabular}

